\title{
PAPERS
}

\section{Acute gastritis with hypochlorhydria: report of 35 cases with long term follow up}

\author{
W V Harford, C Barnett, E Lee, G Perez-Perez, M J Blaser, W L Peterson
}

Departments of

Internal Medicine, University of Texas Southwestern Medical School, Dallas, Texas, USA, Vanderbilt University School of Medicine, Nashville, Tennessee, USA, and Medical Service, Department of

Veterans Affairs

Medical Centers at Dallas and Nashville, USA

W V Harford

C Barnett

E Lee

G Perez-Perez

M J Blaser

W L Peterson

Correspondence to: Dr W V Harford, DVAMC, 111B1, 4500 South Lancaster Road, Dallas, Texas 75216, USA. Email: wharford@worldnet.att.net

Accepted for publication 9 May 2000

\begin{abstract}
Background-Between 1976 and 1987, 35 cases of acute gastritis with hypochlorhydria (AGH) were seen in our research laboratory. The aims of this study were to determine the natural history of AGH and the role of Helicobacter pylori in its pathogenesis.

Methods-Archived serum and gastric biopsy samples obtained from AGH subjects were examined for evidence of $H$ pylori colonisation. Twenty eight of 33 (85\%) surviving AGH subjects returned a mean of 12 years after AGH for follow up studies, including determination of $H$ pylori antibodies, basal and peak acid output, endoscopy, and gastric biopsies. A matched control group underwent the same studies.

Results-Archived material provided strong evidence of new $\boldsymbol{H}$ pylori acquisition in a total of 14 subjects within two months, in 18 within four months, and in 22 within 12 months of recognition of AGH. Prevalence of $\boldsymbol{H}$ pylori colonisation at follow up was $82 \%$ ( 23 of 28 ) in AGH subjects, significantly $(p<0.05)$ higher than in matched controls (29\%). Basal and peak acid output returned to pre-AGH levels in all but two subjects.

Conclusions-One of several possible initial manifestations of $\boldsymbol{H}$ pylori acquisition in adults may be AGH. While $H$ pylori colonisation usually persists, hypochlorhydria resolves in most subjects.

(Gut 2000;47:467-472)
\end{abstract}

Keywords: Helicobacter pylori; acute gastritis; gastric acid secretion; hypochlorhydria

A cluster of cases of acute hypochlorhydria was first noted in our research laboratory in Dallas, Texas, from November 1976 to June 1977. Seventeen of 37 healthy volunteers participating in gastric secretory studies and one patient with Zollinger-Ellison syndrome (ZES) became acutely hypochlorhydric, defined as a decrease in peak acid output to pentagastrin of at least $75 \%$. Twelve subjects consented to gastric mucosal biopsy and in each case severe, active, superficial gastritis was found. Acid secretion returned to near baseline levels in 14 of 18 subjects after an average of four months.
An infectious agent was sought but none was found. ${ }^{1}$ Our laboratory procedures were reviewed with the object of reducing potential sources of person-to-person transmission of an infectious agent. Sharing of glass $\mathrm{pH}$ electrodes among subjects was discontinued. Despite this and other precautions, 17 additional cases were recognised between July 1977 and December 1987 , bringing to 35 the total number of cases observed in our laboratory. We propose the term acute gastritis with hypochlorhydria $(\mathrm{AGH})$ for this syndrome, and the first purpose of this study was to determine its natural history. Additionally, because abrupt hypochlorhydria has been reported in three individuals recently infected with Helicobacter pylori, ${ }^{2-4}$ we wished to determine whether $H$ pylori infection caused the syndrome noted in our subjects.

\section{Methods}

We attempted to locate all subjects observed to have had AGH in our laboratory and invited all to return for follow up studies as paid volunteers. A paired control subject matched for the age of the AGH subject at the time of follow up, as well as for sex, race, and profession was recruited for each $\mathrm{AGH}$ subject who agreed to return. In addition, archived serum and mucosal biopsy specimens from the 35 subjects at varying times in relation to the development of AGH were retrieved and studied as noted below.

\section{QUESTIONNAIRE}

Each AGH subject and matched control completed a written questionnaire regarding upper gastrointestinal symptoms, current tobacco or alcohol use, and use of antacids, $\mathrm{H}_{2}$ receptor antagonists, bismuth compounds, antibiotics, or non-steroidal anti-inflammatory drugs (NSAIDs) during the week prior to follow up studies. Subjects were not questioned regarding proton pump inhibitors as these drugs had only recently been approved in the USA and were not widely prescribed.

Abbreviations used in this paper: $\mathrm{AGH}$, acute gastritis with hypochlorhydria; $\mathrm{BAO}$, basal acid output; OGD, oesophagogastroduodenoscopy; DU, duodenal ulcer; IgG, immunoglobulin G; IgM, immunoglobulin M; PAO, peak acid output; ZES, Zollinger-Ellison syndrome. 
GASTRIC SECRETORY STUDIES

After an overnight fast, consenting $\mathrm{AGH}$ and control subjects had a nasogastric tube placed in the gastric antrum under fluoroscopic guidance, after which basal and peak acid output to pentagastrin were measured as previously described. ${ }^{1}$ The technicians performing the gastric studies were not blinded as to the identity of the subjects.

SERUM ANTIBODIES TO $H$ PYLORI

Archived and prospectively obtained serum samples were coded and analysed under blinded conditions by two of the authors. Sera were examined for $H$ pylori whole cell specific IgG and $\operatorname{IgM}$ antibodies, as well as IgG antibodies to the CagA protein, by enzyme linked immunosorbent assays, as previously described. ${ }^{5-8} \mathrm{~A}$ doubling of the serum IgM titre was considered evidence of recent infection.

ENDOSCOPIC EXAMINATION AND GASTRIC

BIOPSIES

Each consenting AGH subject returning for follow up and his or her matched control subject underwent oesophagogastroduodenoscopy (OGD) after an overnight fast using either an Olympus GIF XQ20 or P-2 gastroscope (Olympus Corporation, New York, New York, USA). After endoscopic examination of the oesophagus, stomach, and duodenum, two mucosal pinch biopsies each were taken using standard forceps from the fundus approximately $5 \mathrm{~cm}$ distal to the gastro-oesophageal junction, the antrum approximately $2 \mathrm{~cm}$ proximal to the pylorus, and the duodenal bulb. Biopsies were fixed in $10 \%$ formalin, embedded in paraffin, and subsequently sectioned and stained with haematoxylin and eosin (and, if necessary, Giemsa stain) for histological examination.

EXAMINATION OF MUCOSAL BIOPSIES

Mucosal biopsy specimens obtained during the follow up study were coded and examined by one of the authors who was unaware of the identity of the subjects. Previous biopsies that had been obtained from 16 of 35 AGH subjects during and at various times after recognition of AGH were retrieved, coded, and re-examined. All specimens were examined for the presence of gastritis and $H$ pylori. Chronic superficial gastritis was defined as the presence of neutrophils and/or mononuclear cells confined to the lamina propria between the pits. ${ }^{9}$ Chronic atrophic gastritis was defined as full thickness involvement of the mucosa by an inflammatory infiltrate and atrophy of the glands, with or without intestinal metaplasia. ${ }^{9}$ Gastritis was defined as active if a neutrophilic infiltrate was found. ${ }^{9} \mathrm{H}$ pylori were classified as present or absent. When $H$ pylori were not seen on sections stained with haematoxylin and eosin, an additional section was examined with Giemsa stain. Only those biopsies negative for $H$ pylori with both stains were classified as negative.
STATISTICAL ANALYSIS

Results are expressed as mean (SEM). Differences between AGH and control subjects were tested by two tailed group $t$ test with $\mathrm{p}<0.05$ considered significant. Differences between AGH subjects prior to hypochlorhydria and on follow up were tested by two tailed paired $t$ test. The adjusted $\chi^{2}$ test with Yates' correction was used for tests of significance between proportions, with $\mathrm{p}<0.05$ considered significant.

\section{INFORMED CONSENT}

This study was approved by the Human Studies Subcommittee of the Research Committee of the Department of Veterans Affairs Medical Center at Dallas. Each subject gave informed written consent.

\section{Results}

Two subjects died, one of metastatic gastrinoma and the other of a non-gastrointestinal illness. Twenty eight (85\%) of the 33 surviving AGH subjects participated in some or all of the follow up studies. The remaining five patients could not be contacted. At the time of follow up, questionnaires and sera were obtained from all 28 of the participating AGH subjects. OGD with biopsies was performed in 22 and acid secretory studies in 21 . Mean and median intervals from initial discovery of $\mathrm{AGH}$ to follow up were 12 years (range 3-14).

Median age and range of $\mathrm{AGH}$ subjects at follow up and matched control subjects were 40 years (32-68) and 40 (28-67), respectively. There were 20 men and eight women as well as 27 Caucasians and one African American in each group. Of the AGH subjects, 20 were clerical or non-medical professionals, one a manual labourer, four were physicians, and three were nurses or medical research technicians at the time of follow up. Of the control subjects, 18 were clerical or non-medical professionals, one a manual labourer, four were physicians, and five were nurses or medical research technicians. Two AGH subjects with a history of duodenal ulcer were matched with two controls with a similar history.

STATUS OF AGH PATIENTS AT FOLLOW UP

COMPARED WITH MATCHED CONTROLS

Symptoms on questionnaire

Frequent dyspepsia, defined as occurring more than once a week, was reported by four of 28 AGH subjects and by two of 28 control subjects (NS). One of the four AGH subjects with dyspepsia experienced new onset of a duodenal ulcer 11 years after the episode of AGH.

\section{Gastric secretory studies}

For the 21 subjects who consented to follow up acid secretory studies, mean (SEM) basal acid output (BAO) before AGH was 3.4 (0.6) $\mathrm{mmol} / \mathrm{h}$ compared with $2.2(0.6) \mathrm{mmol} / \mathrm{h}$ at follow up (NS). BAO in $\mathrm{AGH}$ subjects at follow up was significantly lower than BAO of matched control subjects $(6.0(1.3) \mathrm{mmol} / \mathrm{h}$; $\mathrm{p}<0.01)$. Peak acid output $(\mathrm{PAO})$ in $\mathrm{AGH}$ subjects was $36.6(2.2) \mathrm{mmol} / \mathrm{h}$ before AGH, 32.6 (3.8) $\mathrm{mmol} / \mathrm{h}$ at the time of follow up, and 39.6 


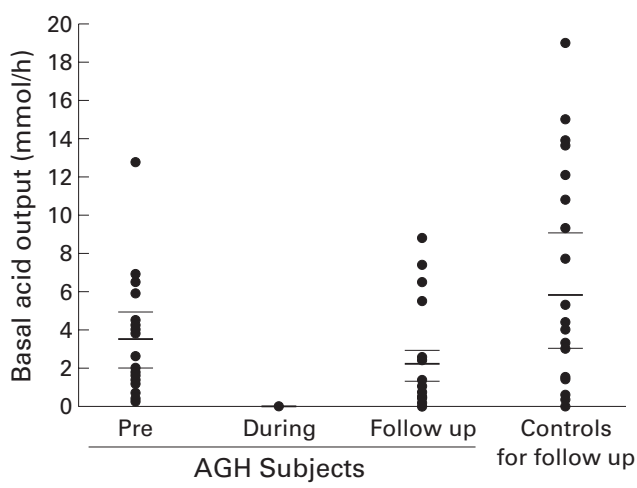

Figure 1 Basal acid output in patients with acute gastritis with hypochlorhydria $(A G H)$ and in control subjects. Basal acid output in $A G H$ subjects was measured pre- $A G H$, during $A G H$, and at follow up after $A G H$. Control subjects were matched for $A G H$ subjects at follow up $(n=21$ for all groups). Horizontal bars represent mean (SEM).

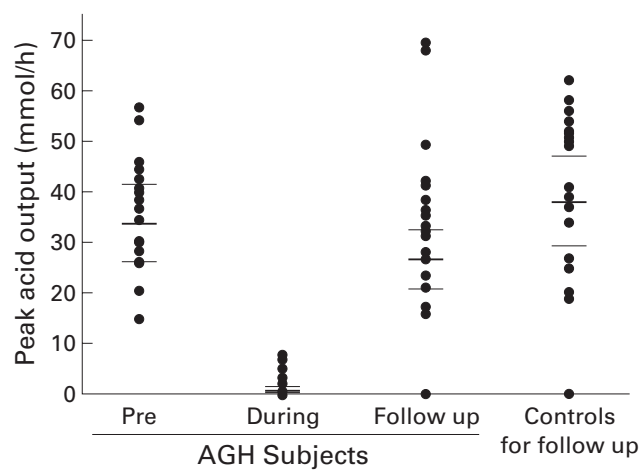

Figure 2 Peak acid output in patients with acute gastritis with hypochlorhydria $(A G H)$ and in control subjects. Peak acid output in AGH subjects was measured pre-AGH, during $A G H$, and at follow up after AGH. Control subjects were matched for AGH subjects at follow up $(n=21$ for all groups). Horizontal bars represent mean (SEM).

(2.9) $\mathrm{mmol} / \mathrm{h}$ in the matched control subjects (NS). Two of $22 \mathrm{AGH}$ subjects (9\%) remained achlorhydric nine and 11 years after AGH. Both of these subjects had evidence of $H$ pylori infection. The difference between BAO in $\mathrm{AGH}$ subjects at follow up and $\mathrm{BAO}$ of matched control subjects remained significant $(p<0.05)$ if the two persistently hypochlorhydric subjects were excluded. Figures 1 and 2 summarise the data on the course of BAO and $\mathrm{PAO}$ in subjects with AGH.

Of the 21 subjects who underwent follow up gastric secretory studies, 12 had antibodies to Cag A protein and nine did not. Mean (SEM) $\mathrm{BAO}$ of Cag A positive subjects was $1.2(0.6)$ $\mathrm{mmol} / \mathrm{h}$ compared with $3.0(1.1) \mathrm{mmol} / \mathrm{h}$ in Cag A negative subjects (NS). Mean (SEM) PAO of Cag A positive subjects was 26.6 (5.7) $\mathrm{mmol} / \mathrm{h}$ and $38.9(13.1) \mathrm{mmol} / \mathrm{h}$ in Cag A negative subjects (NS).

\section{Serological findings}

IgG antibodies to $H$ pylori whole cells were positive in $23(82 \%)$ of $28 \mathrm{AGH}$ subjects but in only eight $(29 \%)$ of 28 matched controls $(\mathrm{p}<0.05)$. Of the $23 \mathrm{IgG}$ positive $\mathrm{AGH}$ subjects, 14 also had antibodies to CagA protein while nine did not.
Endoscopic findings

At the time of follow up, none of the $22 \mathrm{AGH}$ subjects undergoing endoscopy had gastric or duodenal ulceration. One $\mathrm{AGH}$ subject had duodenal erosions. Of the control subjects, two were found to have antral erosions and two others had active duodenal ulcers; both subjects with ulcers were $H$ pylori positive.

\section{Histological findings}

Histological gastritis of the fundus and/or antrum was significantly more common in the 22 AGH subjects than in their matched controls $(86 \%$ v 36\%; $\mathrm{p}<0.01)$. Mucosal biopsies of the gastric fundus obtained in $22 \mathrm{AGH}$ subjects at the time of follow up revealed normal histology in three, chronic active superficial gastritis in $18(82 \%)$, and chronic atrophic gastritis with intestinal metaplasia of the fundus in one. This latter subject (JRE) was one of the two who was persistently achlorhydric at follow up. The other persistently achlorhydric subject (KWR) declined OGD and biopsy. Biopsies of the antrum in the 22 AGH subjects revealed normal histology in four, chronic active superficial gastritis in 17 $(77 \%)$, and atrophic gastritis in one. In contrast, chronic active superficial gastritis of the fundus and antrum were present in only $7 / 22(32 \%)$ and $8 / 22(36 \%)$ of control subjects, respectively $(\mathrm{p}<0.01$ compared with AGH subjects). All but one of the 19 AGH and eight control subjects with gastritis also had evidence of $H$ pylori by biopsy. Additionally, the presence of $H$ pylori on gastric biopsy correlated well with serological results. Of the 21 subjects for whom both biopsy and serology were available, discordance occurred in only one subject (DLA) (table 1).

\section{H PYLORI STATUS OF SUBJECTS BEFORE AND} WITHIN 12 MONTHS OF AGH

Subjects were considered to be $H$ pylori negative when $H$ pylori were not seen on biopsy, when IgG whole cell and CagA antibodies were not present, and when $\operatorname{IgM}$ antibody conversion had not been documented. Conversely, subjects were considered to be $H$ pylori positive when any one of the above tests was found to be positive.

\section{$H$ pylori negative prior to recognition of $A G H$}

Sixteen subjects were documented to be $H$ pylori negative before recognition of $\mathrm{AGH}$ (table 1). Of these, nine were first documented as $H$ pylori positive within two months of $\mathrm{AGH}$, two between two to four months, and three between four and 12 months. In total, 14 (88\%) of these 16 subjects had evidence of $H$ pylori acquisition within 12 months of recognition of $\mathrm{AGH}$.

$H$ pylori negative on first serum sample $(<12$ months) after recognition of $A G H$

Six subjects were $H$ pylori negative on the first serum sample, obtained within the first 12 months after recognition of $\mathrm{AGH}$ (table 1). Of these, one was documented as $H$ pylori positive four months after recognition of $\mathrm{AGH}$, another 
Table 1 Relationship of acute gastritis with hypochlorhydria (AGH) to Helicobacter pylori acquisition. Evidence of $H$ pylori status before and after recognition for each AGH subject is summarised

\begin{tabular}{|c|c|c|c|c|c|c|}
\hline \multirow[b]{2}{*}{ Subject } & \multicolumn{2}{|c|}{ Antibodies prior to $A G H$} & \multicolumn{4}{|c|}{ Evidence of $H$ pylori acquisition after $A G H$ recognition } \\
\hline & $>2 m$ & $0-2 m$ & $<2 m$ after & $2-4 m$ after & $>4-12 m$ after & At follow up \\
\hline \multicolumn{7}{|c|}{ H pylori negative prior to recognition of $\mathrm{AGH}(\mathrm{n}=16)$} \\
\hline JDE & $\mathrm{g}, \mathrm{c}$ & - & $\mathrm{g}, \mathrm{M}, \mathrm{B}, \mathrm{c}$ & $\mathrm{G}, \mathrm{c}$ & $\mathrm{G}, \mathrm{B}, \mathrm{c}$ & $\mathrm{G}, \mathrm{B}, \mathrm{c}$ \\
\hline KJE & $\mathrm{g}, \mathrm{c}$ & - & $\mathrm{g}, \mathrm{M}, \mathrm{B}, \mathrm{c}$ & - & $\mathrm{G}, \mathrm{C}$ & $\mathrm{G}, \mathrm{B}, \mathrm{C}$ \\
\hline HDI & $\mathrm{g}, \mathrm{c}$ & - & $\mathrm{G}, \mathrm{M}, \mathrm{B}, \mathrm{c}$ & $\mathrm{G}, \mathrm{B}, \mathrm{c}$ & $\mathrm{G}, \mathrm{B}, \mathrm{c}$ & $\mathrm{G}, \mathrm{B}, \mathrm{c}$ \\
\hline $\mathrm{BMO}$ & $\mathrm{g}, \mathrm{c}$ & & $\mathrm{G}, \mathrm{M}, \mathrm{b}, \mathrm{c}$ & $\mathrm{G}, \mathrm{C}$ & $\mathrm{G}, \mathrm{C}$ & $\mathrm{G}, \mathrm{B}, \mathrm{C}$ \\
\hline BRO & $\mathrm{g}, \mathrm{c}$ & - & $\mathrm{G}, \mathrm{m}, \mathrm{b}, \mathrm{C}$ & $\mathrm{G}, \mathrm{m}, \mathrm{C}$ & $\mathrm{G}, \mathrm{m}, \mathrm{B}, \mathrm{C}$ & $\mathrm{G}, \mathrm{B}, \mathrm{C}$ \\
\hline TBA & $\mathrm{g}, \mathrm{c}$ & - & $\mathrm{G}, \mathrm{m}, \mathrm{c}$ & - & - & $\mathrm{G}, \mathrm{B}, \mathrm{c}$ \\
\hline SSM & $\mathrm{g}, \mathrm{c}$ & - & $\mathrm{g}, \mathrm{m}, \mathrm{B}, \mathrm{c}$ & $\mathrm{G}, \mathrm{m}, \mathrm{c}$ & $\mathrm{G}, \mathrm{M}, \mathrm{B}, \mathrm{c}$ & $\mathrm{G}, \mathrm{B}, \mathrm{c}$ \\
\hline CPE & $\mathrm{g}, \mathrm{c}$ & - & B & B & $\mathrm{G}, \mathrm{M}, \mathrm{c}$ & $\mathrm{G}, \mathrm{B}, \mathrm{c}$ \\
\hline SLA & $\mathrm{g}, \mathrm{c}$ & - & $\mathrm{g}, \mathrm{m}, \mathrm{C}$ & - & $\mathrm{G}, \mathrm{C}$ & $\mathrm{G}, \mathrm{C}$ \\
\hline WWA & $\mathrm{g}, \mathrm{c}$ & - & - & $\mathrm{G}, \mathrm{m}, \mathrm{c}$ & $\mathrm{G}, \mathrm{m}, \mathrm{b}, \mathrm{c}$ & - \\
\hline PBA & $\mathrm{g}, \mathrm{c}$ & - & $\mathrm{g}, \mathrm{m}, \mathrm{b}, \mathrm{c}$ & - & $\mathrm{g}, \mathrm{m}, \mathrm{B}, \mathrm{c}$ & $\mathrm{G}, \mathrm{B}, \mathrm{c}$ \\
\hline WWO & $\mathrm{g}, \mathrm{c}$ & - & - & - & $\mathrm{G}, \mathrm{M}, \mathrm{B}, \mathrm{C}$ & - \\
\hline THO & $\mathrm{g}, \mathrm{c}$ & - & - & - & - & $\mathrm{G}, \mathrm{C}$ \\
\hline SWI & - & $\mathrm{g}, \mathrm{c}$ & $\mathrm{g}, \mathrm{m}, \mathrm{c}$ & $\mathrm{G}, \mathrm{m}, \mathrm{c}$ & - & $\mathrm{g}, \mathrm{b}, \mathrm{c}$ \\
\hline RRA & - & $\mathrm{g}, \mathrm{c}$ & $\mathrm{g}, \mathrm{m}, \mathrm{c}$ & $\mathrm{g}, \mathrm{m}, \mathrm{c}$ & $\mathrm{G}, \mathrm{m}, \mathrm{C}$ & $\mathrm{g}, \mathrm{b}, \mathrm{c}$ \\
\hline PMA & - & $\mathrm{g}, \mathrm{c}$ & - & - & - & $\mathrm{g}, \mathrm{c}$ \\
\hline \multicolumn{7}{|c|}{ H pylori negative on first sample ( $<12$ months) after recognition of AGH $(n=6)$} \\
\hline RSH & - & - & $\mathrm{g}, \mathrm{m}, \mathrm{b}, \mathrm{c}$ & B & $\mathrm{G}, \mathrm{m}, \mathrm{C}$ & $\mathrm{G}, \mathrm{B}, \mathrm{c}$ \\
\hline JTR & - & - & $\mathrm{g}, \mathrm{c}$ & - & $\mathrm{G}, \mathrm{m}, \mathrm{C}$ & $\mathrm{G}, \mathrm{B}, \mathrm{C}$ \\
\hline JWE & - & - & $\mathrm{g}, \mathrm{c}$ & - & $\mathrm{G}, \mathrm{C}$ & $\mathrm{G}, \mathrm{C}$ \\
\hline LMA & - & - & $\mathrm{g}, \mathrm{c}$ & - & - & $\mathrm{G}, \mathrm{B}, \mathrm{C}$ \\
\hline JBA & - & - & - & $\mathrm{g}, \mathrm{c}$ & $\mathrm{g}, \mathrm{m}, \mathrm{b}, \mathrm{c}$ & $\mathrm{g}, \mathrm{b}, \mathrm{c}$ \\
\hline $\mathrm{CMY}$ & - & - & - & - & $\mathrm{g}, \mathrm{b}, \mathrm{c}$ & $\mathrm{g}, \mathrm{c}$ \\
\hline \multicolumn{7}{|c|}{ H pylori positive before recognition of $\mathrm{AGH}(\mathrm{n}=8)$} \\
\hline DLA & $\mathrm{G}, \mathrm{c}$ & - & $\mathrm{b}$ & $\mathrm{G}, \mathrm{m}, \mathrm{b}, \mathrm{c}$ & & $\mathrm{G}, \mathrm{b}, \mathrm{c}$ \\
\hline $\mathrm{JCO}$ & - & $\mathrm{G}, \mathrm{M}, \mathrm{c}$ & $\mathrm{G}, \mathrm{c}$ & - & $\mathrm{G}, \mathrm{c}$ & - \\
\hline $\mathrm{RCO}$ & - & $\mathrm{G}, \mathrm{M}, \mathrm{c}$ & $\mathrm{G}, \mathrm{c}$ & & - & - \\
\hline MGA & - & $\mathrm{G}, \mathrm{c}$ & $\mathrm{G}, \mathrm{M}, \mathrm{c}$ & $\mathrm{G}, \mathrm{c}$ & $\mathrm{G}, \mathrm{c}$ & $\mathrm{G}, \mathrm{B}, \mathrm{c}$ \\
\hline MNE & - & $\mathrm{g}, \mathrm{C}$ & $\mathrm{G}, \mathrm{M}, \mathrm{C}$ & - & - & $\mathrm{G}, \mathrm{B}, \mathrm{C}$ \\
\hline EHA & - & $\mathrm{G}, \mathrm{c}$ & $\mathrm{G}, \mathrm{B}, \mathrm{c}$ & $\mathrm{G}, \mathrm{c}$ & $\mathrm{G}, \mathrm{B}, \mathrm{C}$ & $\mathrm{G}, \mathrm{B}, \mathrm{C}$ \\
\hline BDE & - & $\mathrm{G}, \mathrm{c}$ & $\mathrm{G}, \mathrm{m}, \mathrm{c}$ & $\mathrm{G}, \mathrm{m}, \mathrm{C}$ & - & - \\
\hline TCO & - & $\mathrm{G}, \mathrm{c}$ & & Only 1 sam & lable for this su & \\
\hline \multicolumn{7}{|c|}{ H pylori positive on first sample ( $<4$ months) after recognition of $\mathrm{AGH}(\mathrm{n}=5)$} \\
\hline BBR & - & - & $\mathrm{g}, \mathrm{M}, \mathrm{B}, \mathrm{c}$ & $\mathrm{g}, \mathrm{c}$ & $\mathrm{G}, \mathrm{B}, \mathrm{C}$ & $\mathrm{G}, \mathrm{B}, \mathrm{C}$ \\
\hline KWR & - & - & $\mathrm{G}, \mathrm{c}$ & $\mathrm{G}, \mathrm{c}$ & $\mathrm{G}, \mathrm{M}, \mathrm{C}$ & $\mathrm{G}, \mathrm{C}$ \\
\hline JRE & - & - & $\mathrm{G}, \mathrm{C}$ & - & $\mathrm{G}, \mathrm{m}, \mathrm{C}$ & $\mathrm{G}, \mathrm{C}$ \\
\hline PBR & - & - & & $\mathrm{g}, \mathrm{C}$ & $\mathrm{G}, \mathrm{C}$ & $\mathrm{G}, \mathrm{B}, \mathrm{C}$ \\
\hline GLE & - & - & $\mathrm{G}, \mathrm{C}$ & Only 1 sam & lable for this su & \\
\hline
\end{tabular}

Capital letters indicate a positive test and lower case letters a negative test; - , no specimen available.

G, g, H pylori whole cell IgG antibody; M, m, H pylori whole cell IgM antibody; C, c, H pylori CagA IgG antibody; B, b, $H$ pylori observed on gastric mucosal histology.

at six months, and a third at 12 months. Three subjects had no evidence of $H$ pylori at any time during the first 12 months after AGH.

$H$ pylori positive before recognition of $A G H$

Eight subjects were $H$ pylori positive based on IgG antibodies to whole cell or to CagA before recognition of $\mathrm{AGH}$ (table 1). Of these, four subjects $(50 \%)$ had documented IgM seroconversion between two months before and two months after recognition of $\mathrm{AGH}$.

$H$ pylori positive on first serum sample $(<4$ months) after recognition of $A G H$

Five subjects were $H$ pylori positive on the first sample available, which was within one month of recognition of $\mathrm{AGH}$ in four subjects and within three months in the other (table 1). Of these five subjects, one had documented IgM seroconversion within the first month.

In summary, of the $35 \mathrm{AGH}$ subjects, there was evidence of recent acquisition of $H$ pylori (either by $\operatorname{IgG}, \mathrm{CagA}$, or $\operatorname{IgM}$ seroconversion or by demonstration of organisms on biopsy) in 22 $(63 \%)$. This is a minimal estimate as pre-AGH samples were not available in 11 subjects.

\section{Discussion}

The ability of the adult human stomach to secrete acid in response to a maximal stimulus is usually constant over time. ${ }^{10}$ However, cases of abrupt spontaneous decrease in maximal acid secretion have been reported, including several in ZES patients. ${ }^{41-23}$ In cases in which gastric mucosal biopsies were obtained, including subjects in our initial cohort, gastritis was noted, leading to the term acute gastritis with hypochlorhydria (AGH) for this syndrome. In the two epidemics in which an infectious aetiology was sought, none was found. ${ }^{121}$

Since the recognition of $H$ pylori, there have been several reports of intentional or accidental inoculation with $H$ pylori in which acute gastritis and hypochlorhydria were noted..$^{2-4} 23$ Stimulated by these reports, we addressed the possibility that acute $H$ pylori acquisition was responsible for the $\mathrm{AGH}$ cases we had observed. We also sought to determine the long term natural history of AGH by re-studying as many of our AGH subjects as we could locate.

\section{RELATIONSHIP BETWEEN AGH AND H PYLORI}

The nature of our data poses obstacles to determining the exact temporal relationship between $\mathrm{AGH}$ and $H$ pylori acquisition. During the time that AGH was being observed, volunteers participating in gastric secretory studies were not visiting our laboratory at regular intervals. Since AGH was asymptomatic in the majority of subjects, its precise onset could not be determined and its recognition was likely delayed in many cases. Serum samples and 
gastric biopsies were not obtained at regular intervals in all $\mathrm{AGH}$ subjects during acute AGH or during recovery. Most gastric biopsies during AGH were obtained with a hydraulic suction tube, and in some cases the biopsy material available for review was limited. Nevertheless, despite these limitations, data from these subjects strongly associates AGH with acute acquisition of $H$ pylori.

A close temporal association between $H$ pylori acquisition and $\mathrm{AGH}$ was documented in the majority of our subjects. Fourteen subjects $(40 \%)$ had evidence of new $H$ pylori acquisition within two months before or after AGH recognition, a total of 17 (49\%) by four months after AGH recognition, and $22(63 \%)$ by 12 months. By the time of follow up, evidence of $H$ pylori acquisition had been documented in all but three of $35 \mathrm{AGH}$ subjects, and the prevalence of $H$ pylori colonisation in $\mathrm{AGH}$ subjects was substantially greater than in matched control subjects.

Although $40 \%$ of subjects had convincing evidence of new $H$ pylori acquisition within two months of the time of recognition of AGH, evidence was either delayed, uncertain, or never present in the others. There are several possible explanations for these observations. Firstly, evidence of infection may have been missed or delayed because of limited biopsy and serological material. Secondly, the timing of the serological response may differ considerably from subject to subject. Thirdly, detection of $H$ pylori in biopsy material may be difficult early on in the course of the infection. Indeed, failure to detect $H$ pylori in biopsies taken soon after the recognition of $\mathrm{AGH}$ has been observed. ${ }^{22}$ This may be a result of a vigorous inflammatory response or variations in bacterial growth due to differences in host environmental conditions, such as local $\mathrm{pH}$. A fourth possibility is that some subjects may have had only transient $H$ pylori colonisation, with spontaneous clearing. Such a pattern has been noted in both accidental human infection and experimental $H$ pylori challenge of primates. ${ }^{24}{ }^{25}$ Finally, it is possible that $\mathrm{AGH}$ was caused by an agent other than $H$ pylori and that, perhaps due to hypochlorhydria, subjects were predisposed to secondary $H$ pylori infection, although this seems unlikely.

If, as we believe, AGH was caused by $H$ pylori acquisition, the route of transmission remains unclear. Evidence supports transmission of $H$ pylori through close personal contact, perhaps by the oral-oral or gastro-oral route. ${ }^{26}$ Cases of accidental infection through endoscopic procedures or laboratory accidents have been documented. ${ }^{3232427-29}$ Early in our epidemic, we speculated that common $\mathrm{pH}$ electrodes used to measure the acidity of withdrawn specimens of gastric juice, after which the specimens were returned to the subjects' stomachs, may have permitted transmission of an infectious agent from one subject to another. However, this seems unlikely to have been the only potential source of infection, as although the incidence of cases declined after using separate electrodes for each subject, further cases occurred, albeit less frequently. Other mechanisms of person-to-person trans- mission are likely. Our laboratory was dealing with multiple samples of gastric secretions on a daily basis. A number of subjects and some laboratory personnel were likely to have been previously colonised with $H$ pylori. Colonisation of research subjects may have been facilitated by the fact that many were participating in studies in which hypochlorhydria was being induced by antacids or antisecretory medications. In the two reported cases of successful voluntary $H$ pylori self-inoculation, the investigators produced temporary hypochlorhydria by premedication with cimetidine. ${ }^{2} 30$ Indeed, other laboratories known for their frequent acid secretory studies have reported similar syndromes. ${ }^{21}$

Our study provided the opportunity to assess the natural history of AGH as most of our subjects returned for follow up a mean of 12 years after the illness. Firstly, $H$ pylori persisted in all but two subjects found to have acquired it at some time during the first year after illness, suggesting that once colonisation is established, it seldom resolves spontaneously. Secondly, our subjects were largely asymptomatic at follow up, with no greater prevalence of dyspepsia than matched controls. Thirdly, BAO in AGH subjects at follow up was significantly lower than BAO in matched control subjects even after excluding the persistently hypochlorhydric subjects. BAO and PAO returned to pre-AGH levels in all but two subjects, one of whom was found to have atrophic gastritis on biopsy. The reason why mean BAO in our AGH subjects was significantly lower than that of the control group in not known. The mechanisms by which acute $H$ pylori acquisition lead to transient hypochlorhydria are of considerable interest.

Once it became clear that most of our subjects were infected with $H$ pylori, we reported the phenomenon to our human studies subcommittee for advice about what steps we should take. A letter was drafted with the assistance of the committee and mailed to each subject offering treatment and follow up.

Supported by the Department of Veterans Affairs, the Southwestern Digestive Disease Foundation, grants DK 17294, DK 53707, and the Digestive Disease Care Center grant DK 41310 from the National Institutes of Health.

Conflict of interest statement. M Blaser has royalty interests on use of CagA for diagnostic purposes based on Vanderbilt patent.

1 Ramsey EJ, Carey KV, Peterson WL, et al. Epidemic gastritis with hypochlorhydria. Gastroenterology 1979;76:1449tis 57.

2 Morris AJ, Nicholson G. Ingestion of Campylobacter pyloridis causes gastritis and raised fasting gastric pH. Am $\mathcal{F}$ Gastroenterol 1987;82:192-9.

3 Graham DY, Alpert LC, Smith JL, et al. Iatrogenic Campylobacter pylori infection is a cause of epidemic achlorhydria. Am $\mathcal{F}$ Gastroenterol 1988;83:974-80.

4 Sobala GM, Crabtree JE, Dixon MF, et al. Acute Helicobacter pylori infection: clinical features, local and systemic immune response, gastric mucosal histology, and gastric juice ascorbic acid concentrations. Gut 1991;32: 1415-18.

5 Parsonnet J, Blaser MJ, Perez-Perez GI, et al. Symptoms and risk factors of Helicobacter pylori infection in a cohort of epidemiologists. Gastroenterology 1992;102:41-6.

6 Perez-Perez GI, Dwordin BM, Chodos JE, et al. Campylobacter pylori antibodies in humans. Ann Intern Med 1988;109:11-17.

7 Drumm B, Perez-Perez GI, Blaser MJ, et al. Intrafamilial clustering of Helicobacter pylori infection. $N$ Engl $\mathcal{F}$ Med 1990:322:359 Helicot

8 Blaser MJ, Kobayashi K, Cover TL, et al. Helicobacter pylori infection in Japanese patients with adenocarcinoma of the stomach. Int $\mathcal{F}$ Cancer 1993;55:799-802. 
9 Crawford JM. The Gastrointestinal Tract. In: Cotran RS, Kumar V, Robbins SL, eds. Robbins. Pathologic basis of disease, 5 th edn. Philadelphia: WB Saunders, 1994:755-830.

10 White WD, Juniper K. Repeatability of gastric analysis. Dig Dis 1973;18:7-13.

11 Hirschowitz BI, Streeten DHP, Pollard HM, et al. Role of gastric secretions in activation of peptic ulcers by corticotropin (ACTH). $\mathcal{F A M A}$ 1955;158:27-32.

12 Hirschowitz BI, Streeten DHP, London JA, et al. A steroidinduced gastric ulcer. Lancet 1956;2:1081-3.

13 Spiro HM, Schwartz RD. Superficial gastritis. A cause of temporary achlorhydria and hyperpesinemia. $N \mathrm{Engl} F \mathrm{Med}$ 1958;259:682-4.

14 Lawrie RS, Williamson AWR, Hunt JN. Zollinger-Ellison syndrome treated with poldine methyl methosulphate. Lancet 1962;1:1002-4.

15 Melnyk CS, Krippaehne WW, Benson JA, et al. Spontaneous remission of Zollinger-Ellison syndrome. Arch Intern ous remission of Zollinger-Ellison syndrome. Arch Intern
Med 1965;115:42-7.

1967:2:681. 1967;2:681.

17 Waterfall W. Spontaneous decrease in gastric secretory response to humoral stimuli. BMf 1969;4:459-61.

18 Desai HG, Antia FP. Spontaneous achlorhydria with atrophic gastritis in the Zollinger-Ellison syndrome. Gut 1969;10:935-9.

19 Desai HG, Zaveri MP, Antia FP. Spontaneous and persisting decrease in maximal acid output. BMf 1971;2:313-15. 20 Wiersinga WM, Tytgat GN. Clinical recovery owing to tar-
get parietal cell failure in a patient with Zollinger-Ellison syndrome. Gastroenterology 1977;73:1413-17.
21 Gledhill T, Leicester RJ, Addis B, et al. Epidemic hypochlorhydria. BMF 1985;290:1383-6.

22 Griffith JL, Cummings OW, Hirschowitz BI. Development of sustained achlorhydria in a patient with the ZollingerEllison syndrome treated with omeprazole. Gastroenterology 1991;101:242-6.

23 Sonneberg A, Bartmess J, Kern L, et al. Hypochlorhydrie bei akuter Gastritis. Dtsch Med Wochenschr 1979;104:1814-16.

24 Miyaji H, Kohli Y, Azuma T, et al. Endoscopic crossinfection with Helicobacter pylori. Lancet 1995;345:464.

25 Dubois A, Berg DE, Incecik ET, et al. Transient and persistent experimental infection of nonhuman primates with Helicobacter pylori: implications for human disease. Infect Immun 1996;64:2885-91.

26 Axon ATR. Review article: is Helicobacter pylori transmitted by the gastro-oral route? Aliment Pharmacol Ther 1995;9: $585-8$.

27 Tytgat GN. Endoscopic transmission of Helicobacter pylori. Aliment Pharmacol Ther 1995;9:105-10.

28 Matysiak-Budnik T, Briet F, Heyman M, et al. Laboratoryacquired Helicobacter pylori infection. Lancet 1995;346: 1489-90.

29 Takata T, Shirotani T, Okada M, et al. Acute hemorrhagic gastropathy with multiple shallow ulcers and duodenitis caused by a laboratory infection of Helicobacter pylori. caused by a laboratory infection
Gastrointest Endosc 1998;47:291-4.

30 Marshall BJ, Armstrong JA, McGechie DB, et al. Attempt to fulfil Koch's postulates for pyloric campylobacter. Med $\mathcal{F}$ Aust 1985;142:436-9. 